\title{
Influence of Plant Growth Regulators on Growth and Yield of Greenhouse Tomato (Solanum lycopersicum L.)
}

\author{
B. Lathiya Jasmin, Sanjeev Kumar" and Shivani Modi \\ Department of Vegetable Science, ASPEE College of Horticulture and Forestry, Navsari \\ Agricultural University, Navsari-396 450 (Gujarat), India \\ *Corresponding author
}

\section{A B S T R A C T}

\begin{tabular}{|l|}
\hline K e y w o r d s \\
Greenhouse \\
$\begin{array}{l}\text { Tomato, PGRs, } \\
\text { Growth, Yield }\end{array}$ \\
\hline Article Info \\
\hline $\begin{array}{l}\text { Accepted: } \\
\text { 10 July } 2018 \\
\text { Available Online }: \\
10 \text { August } 2018\end{array}$ \\
\hline
\end{tabular}

\section{Keywords}

Greenhouse

Tomato, PGRs,

wth, Yield

\section{Introduction}

Tomato (Solanum lycopersicum L.) is one of the most important greenhouse vegetables belonging to family Solanaceae. It is consumed in a variety of ways like fresh in salads and sandwiches, cooked or processed in ketchup, pickle, puree, sauces or dried powder and preparation of various recipes. Tomato plays an important role in human nutrition by providing essential amino acids, vitamins and minerals (Sanju et al., 2003). It contains lycopene, a very potent antioxidant that may be an important contributor to the prevention of cancers (Agrawal and Rao, 2000). Development of high yielding varieties/hybrids both from public and private sector has significantly played important role in enhancing crop production. In South Gujarat conditions, the period during monsoon doesn't allow outdoor cultivation of tomato.

This period has a lot of potential in terms of providing off-season production and remunerative returns through tomato cultivation. But, tomato cultivation during high humid conditions often faces problems of poor fruit setting due to poor or negligible release of pollens for pollination and fertilization thereby affecting fruit set and ultimately the yield. PGRs (plant growth regulators) play very important role in 
enhancing fruit set and induction of parthenocarpy in various crops.

Under different environmental conditions tomato growth is normally affected by many climatic factors. So, regulation of vegetative and reproductive growth as well as overcoming the problems related to pollination and fertilization for fruit development can be achieved and manipulated through the use of PGRs like auxins and gibberellins. Plant growth regulators (PGRs) are wide category of compounds that can promote, inhibit or change plant physiological or morphological processes at very low concentrations. PGRs can affect rooting, flowering, fruiting and fruit growth, leaf or fruit abscission, senescence, regulation of some metabolic processes and plant resistance to temperature or water stresses. Auxin application induces fruit setting, which ultimately increase the yield of plant.4chlorophenoxyacetic acid (4-CPA) and 2,4dichlorophenoxyacetic acid (2,4-D) are synthetic auxins, which reduce pre-harvest fruit drop with increased number of fruits per plant and yield (Sasaki et al., 2005). Earlier research also indicates increased fruit setting and fruit size in tomato due to application of plant growth regulators such as 2,4-D and 4CPA at low concentrations (Khan et al., 2006). The most widely available plant growth regulator is $\mathrm{GA}_{3}$ and its application in tomato plants has been shown to induce marked stem elongation, increase fresh weight, accelerate flowering and produce greater numbers of flowers per plant and increase fruit set, (Davies, 1995; Kazemi et al., 2014). It is well documented in the literature that a mixture of 4-CPA and $\mathrm{GA}_{3}$ have shown an increased tomato fruit set and proportion of normal fruits compared to plants of the same crop treated with 4-CPA (Sasaki et al., 2005). Thus, hormonal use in the plant system and their importance is the outstanding discovery and achievement of plant sciences. So, investigation was aimed to find out the suitable plant growth regulators and its concentration for increasing growth and yield in tomato.

\section{Materials and Methods}

\section{About the Location}

The experiment was carried out at Regional Horticultural Research Station, ASPEE College of Horticulture and Forestry, Navsari Agricultural University, Navsari, Gujarat during kharif, 2016 under multispan saw tooth type naturally ventilated polyhouse (NVPH) in tomato cv. Bargad. The location is situated at a latitude and longitude of $20^{\circ} 57^{\prime} \mathrm{N}$ and $72^{\circ}$ $54^{\prime} \mathrm{E}$, respectively with an altitude of about 12 $\mathrm{m}$ above the mean sea level and characterized by high humid climate with high annual rainfall of more than $1600 \mathrm{~mm}$.

\section{Treatment details}

The experiment was planned with fourteen treatments viz., $\mathrm{T}_{1}$ : 4-CPA $20 \mathrm{ppm}, \mathrm{T}_{2}$ : 4-CPA 30 ppm, T3: 4-CPA 40 ppm, T4: 2,4-D 2.50 ppm, $\mathrm{T}_{5}:$ 2,4-D 5.00 ppm, $\mathrm{T}_{6}$ : 2,4-D $7.50 \mathrm{ppm}$, $\mathrm{T}_{7}$ : 4-CPA $20 \mathrm{ppm}$ followed by $\mathrm{GA}_{3}(30 \mathrm{ppm})$ within 24 hours, $\mathrm{T}_{8}$ : 4-CPA $30 \mathrm{ppm}$ followed by $\mathrm{GA}_{3}(30 \mathrm{ppm})$ within 24 hours, $\mathrm{T}_{9}$ :4-CPA $40 \mathrm{ppm}$ followed by $\mathrm{GA}_{3}(30 \mathrm{ppm})$ within 24 hours, $\mathrm{T}_{10}$ : 2,4-D $2.50 \mathrm{ppm}$ followed by $\mathrm{GA}_{3}$ (30 ppm) within 24 hours, $\mathrm{T}_{11}: 2,4-\mathrm{D} 5.00$ ppm followed by $\mathrm{GA}_{3}(30 \mathrm{ppm})$ within 24 hours, $\mathrm{T}_{12}$ : 2,4-D $7.50 \mathrm{ppm}$ followed by $\mathrm{GA}_{3}$ (30 ppm) within 24 hours, $\mathrm{T}_{13}$ : 4-CPA 30 ppm- Inflorescence dipping, $\mathrm{T}_{14}$ : Control in a Randomized Block Design (RBD) with three replications.

\section{Methodology}

Tomato plants were grown on raised beds having dimensions $100 \times 40$ x $50 \mathrm{~cm}$ (Width $\mathrm{x}$ Height $\times$ Path) at the spacing of $60 \times 45 \mathrm{~cm}$ 
and fertigated with $\mathrm{N}: \mathrm{P}: \mathrm{K}$ at the rate of 25 : 12.5: $12.5 \mathrm{~kg} / 1000 \mathrm{~m}^{2}$ along with farmyard manure $\left(2 \mathrm{t} / 1000 \mathrm{~m}^{2}\right)$.The fertigation was scheduled after 10-15 days of planting at weekly interval. The common dose of micronutrient (Grade-5) at the rate of 5 $\mathrm{kg} / 1000 \mathrm{~m}^{2}$ was applied before transplanting the crop. 10 sprays of each treatment were made during cropping span of tomato, First being at the time of $50 \%$ flowering and remaining sprays were done at the interval of 20 days. Spray of $\mathrm{GA}_{3}$ were done within 24 hrs after the spray of 4-CPA and 2,4-D.

Dipping of each truss with 4-CPA was also carried out at weekly interval. Data were taken from randomly selected five plants from each plot on different characters: plant height $(\mathrm{cm})$ at 60, 120, 180 Days after planting (DAP) and at final harvest, leaf area $\left(\mathrm{cm}^{2}\right)$, number of fruits per cluster, fruit setting (\%), number of fruits per plant, days to first picking, days to last picking, average fruit weight $(\mathrm{g})$, fruit yield per plant $(\mathrm{kg})$, fruit yield per $\mathrm{m}^{2}$ as per the standard procedure. The recorded data were statistically analyzed to find out the variation resulting from the experimental treatments by employing ' $F$ ' test at five per cent level of significance on the basis of null hypothesis. The mean values were subjected to statistical analysis through WASP-Web Agri Stat. Package 2.0 developed by Ashok Kumar Jangam and Pranjali Thali at ICAR Research Complex for Goa, Ela, Old God, Goa, India (Anonymous, 2016). Appropriate standard errors (S.Em. \pm ) were calculated in each case and the Critical Difference (CD) at five per cent level of probability was worked out to compare the treatment means.

\section{Results and Discussion}

The Performance of tomato in response to foliar application of different levels of PGRs is presented as mean values with statistical notation in the Table 1.

\section{Vegetative parameters}

The PGRs influenced plant height significantly throughout the growing season of tomato at all the stages of growth except at 60 days after planting, which had non-significant differences among the treatments for plant height. Treatment $\mathrm{T}_{13}$ (4-CPA @30 ppmInflorescence dipping) recorded highest plant height of 203.47, 251.73 and $306.67 \mathrm{~cm}$ at 120, 180 DAP and at final picking, respectively. The maximum plant height displayed by treatment $T_{13}$ at 120 days DAP was statistically at par with treatment $\mathrm{T}_{14}$ $(200.47 \mathrm{~cm}), \mathrm{T}_{7}(193.73 \mathrm{~cm}), \mathrm{T}_{8}(190.47 \mathrm{~cm})$, $\mathrm{T}_{1}(188.67 \mathrm{~cm}), \mathrm{T}_{9}(185.13 \mathrm{~cm}), \mathrm{T}_{2}(183.80$ $\mathrm{cm}), \mathrm{T}_{10}(180.07 \mathrm{~cm})$ and $\mathrm{T}_{3}(178.60 \mathrm{~cm})$. After 180 days of DAP, plant height in the best treatment $\left(\mathrm{T}_{13}\right)$ was statistically at par with treatment $\mathrm{T}_{14}(249.33 \mathrm{~cm}), \mathrm{T}_{7}(243.80$ $\mathrm{cm}), \mathrm{T}_{8}(241.87 \mathrm{~cm}), \mathrm{T}_{1}(238.40 \mathrm{~cm}), \mathrm{T}_{10}$ $(235.27 \mathrm{~cm}), \mathrm{T}_{9}(235.00 \mathrm{~cm}), \mathrm{T}_{2}(233.53 \mathrm{~cm})$, $\mathrm{T}_{3}(2283 \mathrm{~cm})$ and $\mathrm{T}_{11}(228.33 \mathrm{~cm})$. While at final picking, this treatment $\left(\mathrm{T}_{13}\right)$ displayed statistically similar plant height with treatment $\mathrm{T}_{14}(303.00 \mathrm{~cm}), \mathrm{T}_{7}(302.13 \mathrm{~cm}), \mathrm{T}_{8}(299.69$ $\mathrm{cm}), \mathrm{T}_{9}(293.00 \mathrm{~cm}), \mathrm{T}_{1}(290.60 \mathrm{~cm}), \mathrm{T}_{2}$ $(285.53 \mathrm{~cm}), \mathrm{T}_{10}(283.60 \mathrm{~cm})$ and $\mathrm{T}_{11}(280.13$ $\mathrm{cm})$.

It might be due to its effect on rapid cell elongation and multiplication of cells in subapical meristem. The rapid growth as observed under the influence of 4-CPA is a result of both the greater number of cells formed and elongation of individual cells. Karim et al., (2015) in tomato and Das et al., (2015) in bell pepper also substantiated similar trends of increase in plant height during their period of study. Among different levels of PGRs, treatment $\mathrm{T}_{14}$ recorded significantly maximum leaf area $\left(843.33 \mathrm{~cm}^{2}\right)$ per plant, which was at par with $\mathrm{T}_{7}\left(840.00 \mathrm{~cm}^{2}\right), \mathrm{T}_{3}\left(837.00 \mathrm{~cm}^{2}\right), \mathrm{T}_{8}$ $\left(836.00 \mathrm{~cm}^{2}\right), \mathrm{T}_{9}\left(833.00 \mathrm{~cm}^{2}\right), \mathrm{T}_{13}(831.67$ $\left.\mathrm{cm}^{2}\right), \mathrm{T}_{1}\left(823.33 \mathrm{~cm}^{2}\right) \mathrm{T}_{2}\left(814.00 \mathrm{~cm}^{2}\right), \mathrm{T}_{10}$ $\left(770.00 \mathrm{~cm}^{2}\right)$ and $\mathrm{T}_{11}\left(766.00 \mathrm{~cm}^{2}\right)$. 
Table.1 Influence of foliar application of PGRs on vegetative, reproductive and yield attributes of greenhouse tomato

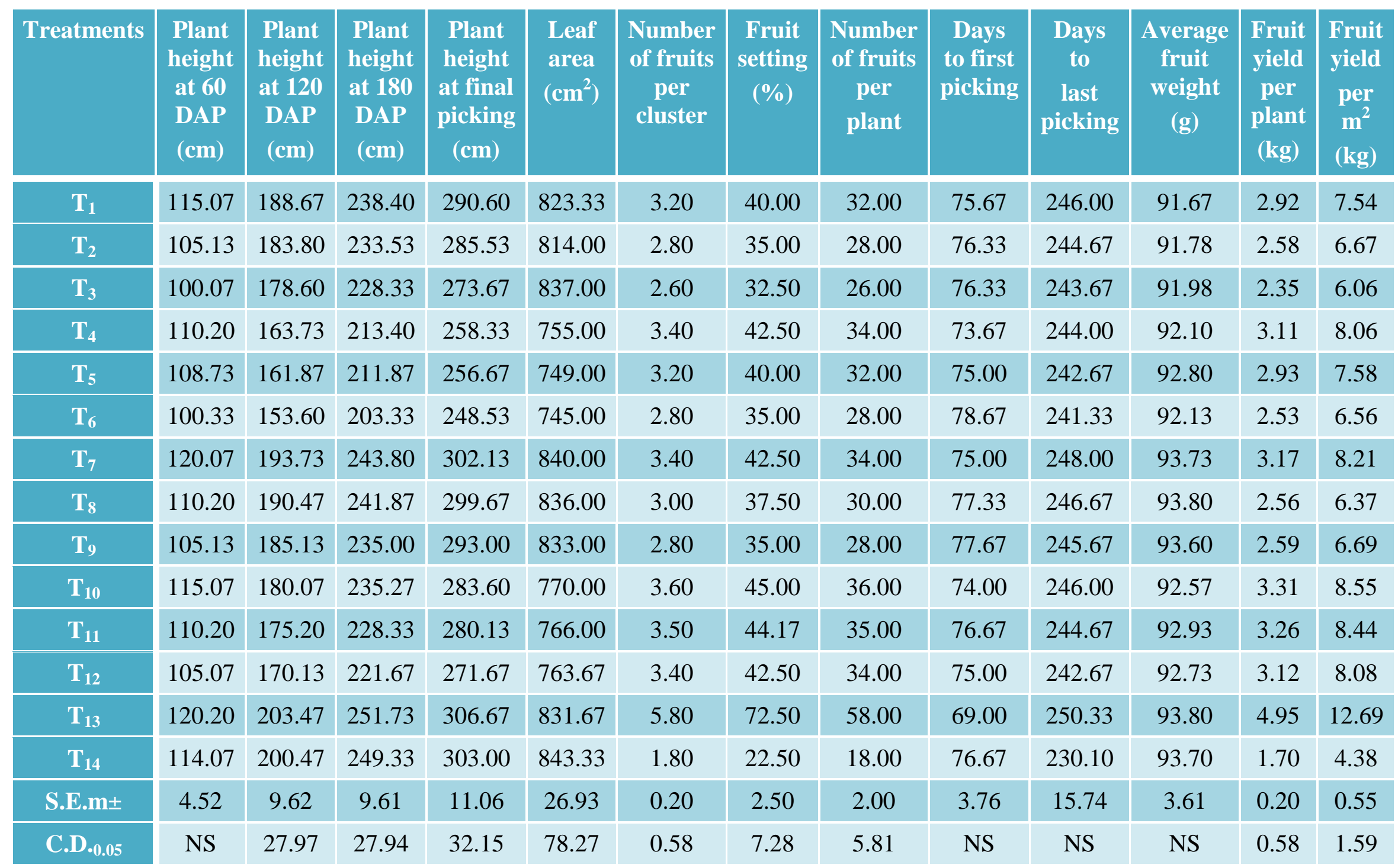


The results are not in agreement with the findings of earlier worker Singh et al., (2012) in bell pepper, who otherwise experienced an increase in leaf area by foliar spray of $\mathrm{GA}_{3}$. This might be due to 4-CPA, 2,4-D and $\mathrm{GA}_{3}$ deviates major portion of photosynthates from vegetative parts of plant to reproductive ones.

\section{Reproductive parameters}

In case of number of fruits per cluster, treatment $\mathrm{T}_{13}$ (4-CPA 30 ppm-Inflorescence dipping) showed significantly highest number of fruits per cluster (5.80), which was at par with the treatment $\mathrm{T}_{11}(3.50), \mathrm{T}_{4}(3.40), \mathrm{T}_{7}$ (3.40), $\mathrm{T}_{12}$ (3.40), $\mathrm{T}_{1}$ (3.20) and $\mathrm{T}_{5}$ (3.20) due to the fact that plants treated with 4- CPA (30 ppm- Inflorescence) dipping remained physiologically more active resulting in earliness, more number of flowers and maximum fruit set. The present findings are in agreement with those reported by Singh et al., (2002), Tonder and Combrink (2003) and Sarkar et al., (2014) in tomato.

Treatment $\mathrm{T}_{13}$ (4- CPA 30 ppm-Inflorescence dipping) also recorded significantly highest fruit set of $72.50 \%$ compared to all other treatments. The $2^{\text {nd }}$ highest fruit set was obtained in treatment $\mathrm{T}_{10}(45.00 \%)$ with statistically similar fruit set in $\mathrm{T}_{11}(44.17 \%)$, $\mathrm{T}_{4}(42.50 \%), \mathrm{T}_{7}(42.50 \%), \mathrm{T}_{12}(42.50 \%), \mathrm{T}_{1}$ $(40.00 \%)$ and $\mathrm{T}_{5}(40.00 \%)$.

This could be attributed to enhanced photosynthetic activity, increased production and accumulation of carbohydrates, favourable effect on vegetative growth and retention of flowers which increased fruit set percentage. 4-CPA also has a potential to induce parthenocarpic fruits and check flowers and fruits drop. These results are in accordance with the findings of Baliyan et al., (2013) and Tonder and Combrink (2003) in tomato and Das et al., (2015) and Sarkar et al., (2015) in bell pepper.
The statistical comparison showed the significant influence of different treatments on number of fruits per plant. However, the maximum number of fruits (58.00) were obtained in the treatment of $\mathrm{T}_{13}$ (4-CPA 30 ppm- Inflorescence dipping), which was statistically superior over all other treatments. This might be due to rapid and better nutrient translocation from roots to apical parts of plant, making treated plants physiologically more active thereby resulting in more number of flowers and higher fruit set percent. On other hand, it also induced parthenocarpic fruit set, thus increased the number of fruits per plant.

The present findings are in agreement with those reported by, Baliyan et al., (2013), Choudhary et al., (2013), Karim et al., (2015) and Rahman et al., (2015) in tomato and Das et al., (2015) and Sarkar et al., (2015) in bell pepper. The mean data analyzed for days to days to first picking and last picking showed non-significant differences among various treatments for this characters.

\section{Yield parameters}

The mean data analyzed for average fruit weight showed non-significant differences among various treatments. However, maximum fruit weight of tomato was found in treatment $\mathrm{T}_{8}(93.80 \mathrm{~g})$.

The fruit yield per plant was significantly maximum $(4.95 \mathrm{~kg})$ under $\mathrm{T}_{13}$ in comparison to remaining levels of PGRs application. It was attributable to higher fruit set percentage and number of fruits per plant. These results are in close agreement with the findings of earlier researchers like Tonder and Combrink (2003), Chaudhary et al., (2013), Sarkar et al., (2014) and Rahman et al., (2015) in tomato and Das et al., (2015) and Sarkar et al., (2015) in bell peper. 
Among different treatments, $\mathrm{T}_{13}$ (4-CPA 30 ppm- Inflorescence dipping) noticed significantly maximum yield per $\mathrm{m}^{2}$ (12.69 $\mathrm{kg}$ ) over all other treatments. This is attributed to the presence of higher fruit set (\%), number of fruits per plant and highest fruit yield per plant. These results are in close agreement with the findings of earlier researchers like Tonder and Combrink (2003), Chaudhary et al., (2013), Karim et al., (2015) and Rahman et al., (2015) in tomato and Das et al., (2015) and Sarkar et al., (2015) in bell peper.

It is inferred from the present study that majority of growth and yield parameters displayed good amount of variability upon foliar application of PGRs in tomato for various horticultural traits under NVPH. Thus, PGRs exerted a profound influence on various horticultural traits and offers a lot of scope to exploit their potential for off season cultivation in protected condition. On the basis of present finding it can be concluded that foliar application of 4-CPA 2,4-D and $\mathrm{GA}_{3}$ has significantly increased growth as well as yield attributes. Among the different plant bio-regulators treatments tried, the inflorescence dipping with 4-CPA at the concentration of $30 \mathrm{ppm}$ gives best result in protected condition, whereas $\mathrm{GA}_{3}$ at $30 \mathrm{ppm}$, was found to be the better as additional spray after 2,4-D (2.5 and $5.00 \mathrm{ppm}$ ) application for boosting up the production of tomato under protected cultivation.

\section{References}

Agarwal, S. and Rao, A. (2000).Tomato lycopene and its role in human health and chronic diseases.Canadian Med. Assoc. J., 166 (6): 739-744.

Anonymous, (2016). http://icargoa.res.in/ wasp2.0. (Date:28/01/2016)

Baliyan S.P. et al., (2013). The effects of 4chlorophenoxyacetic acid plant growth regulator on the fruit set, yield and economic benefit of growing tomatoes in high temperatures. Intl. J. Agri. Sci., 3 (2): 29-36.

Chaudhary, S.et al., (2013). Growth and yield of summer tomato as influenced by plant growth regulators. Intl. $J$. Sustainable Agric., 5 (1): 25-28.

Das, S.K. et al., (2015). Influence of plant growth regulators on yield contributing characters and yield of bell pepper (Capsicum annuum) varieties. J. Plant Sci., 10: 63-69.

Davies, P.J. (1995). Plant hormones, Physiology, Biochemistry and Molecular Biology, Kluwer Academic Publishers, Dardrecht.

Karim, R. et al., (2015). Improvement of summer tomato (Lycopersicon esculentum Mill.) production using 4chlorophenoxy acetic acid.J. Biosci. Agric. Res., 4 (2): 86-91.

Kazemi, M. (2014). Effect of gibberellic acid and potassium spray on vegetable growth and reproduction characteristics of tomato. J. Biol. Environ. Sci., 8 (22): 1-9.

Khan, M.A. et al., (2006). Effect of gibberellic acid spray on performance of tomato. Turkish J. Biol., 30: 11-16.

Rahman, M.et al., (2015). Plant growth regulators promote growth and yield of summer tomato (Lycopersicon esculentum Mill.). Prog. Agric., 26: 3237.

Sanju, M.U. et al., (2003). Mineral nutrition of tomato. Food Agric. \& Environ., 1 (2): 176-183.

Sarkar, D. et al., (2015). Influence of plant growth regulators on yield contributing characters and yield of bell pepper (Capsicum annuum) varieties. J. Plant Sci., 10: 63-69.

Sarkar, M.D. et al., (2014). Flower and fruit setting of summer tomato regulated by 
plant hormones. App. Sci. Report, 7 (3): $117-120$.

Sasaki, H. et al., (2005). Reduction of high temperature inhibition in fruit set by plant growth regulators. Japan Agri. Res., 39: 135-138.

Singh J. et al., (2002). Effect of some plant growth regulators on fruit set and development under cold climatic conditions in tomato (Lycopersicon esculentum Mill.). Progressive Hort., 34 (2): 211-214
Singh, R.N. et al., (2012). Effect of bioregulators on growth and yield parameters of capsicum cultivars under controlled condition. Hort. Flora Res. Spectrum, 1 (1): 50-54.

Tonder, C.S.M.V. and Combrink, N.J.J. (2003). The effect of plant growth regulators on the production of out-ofseason greenhouse tomatoes (Lycopersicon esculentum). South African J. Plant Soil, 20 (4): 165-168.

\section{How to cite this article:}

Lathiya Jasmin, B., Sanjeev Kumar and Shivani Modi. 2018. Influence of Plant Growth Regulators on Growth and Yield of Greenhouse Tomato (Solanum lycopersicum L.). Int.J.Curr.Microbiol.App.Sci. 7(08): 1603-1609. doi: https://doi.org/10.20546/ijcmas.2018.708.183 